\title{
Postmodern Feminist Perspectives in Eat Pray Love
}

\author{
Surabhi Basotia* and Arpit Kothari
}

Department of Languages, Manipal University Jaipur, Rajasthan 303007, India

\begin{abstract}
Postmodern Feminism is the epitome of two massive movements, Postmodernism and Feminism, in literature. It inculcates the features of Postmodernism into Feminism, hence urging feminism to confront and reconstruct its framework. Elizabeth Gilbert's memoir, Eat Pray Love: One Woman's Search for Everything across Italy, India, and Indonesia (2006), deserves scholarly attention as it allows us to apply the notions of the theory on the text and analyze it in the light of the theory. This paper evaluates the points of similarities and/or differences found during the discourse analysis of the chosen text with a focused emphasis on the aspects of 'Non-Essentialism', 'De/Reconstructing the Female Self', and 'Breaking free from the boundaries of cliché Feminism'. The study reveals results which satiate the expectations of a Postmodern Feminist in the form of the protagonist, Elizabeth Gilbert. Gilbert breaks free from her 'Essential' mundane life and embarks on her inward and outward journey of self-discovery and in the process Deconstructs and Reconstructs one's own self.
\end{abstract}

ARTICLE INFO

Article history:

Received: 22 January 2020

Accepted: 1 June 2020

Published: 25 December 2020

DOI: https://doi.org/10.47836/pjssh.28.4.24

E-mail addresses:

surabhibasotia@gmail.com (Surabhi Basotia)

arpit.kothari@jaipur.manipal.edu (Arpit Kothari)

*Corresponding author
Keywords: De/reconstruction of self, gender performativity, non-essentialism, postmodern feminism

\section{INTRODUCTION}

Elizabeth Gilbert is an American writer who is widely acclaimed for her memoir Eat Pray Love: One Woman's Search for Everything Across Italy, India and Indonesia (2006) which was also adapted into a movie in 2010 starring Julia Roberts. Gilbert's memoir presents an enlightening journey 
(literally) of her life which occurred right after her divorce. Her journey to three different countries to seek her lost self serves the purpose of exploring (in Italy), seeking (in India), and finding (in Indonesia) herself. Gilbert's journey has been deconstructed and re-read variously by critics and scholars exploring different aspects like spirituality, food symbolism and how it affects gender identity, travel narratives and the like. Discussion and emphasis on Gilbert's travelling part fail to entirely decipher the reason and socioeconomic background of the author which leads her into taking this journey. This paper attempts to lay a thorough focus into the factors which lead an independent white middle-class woman to still seek emancipation. The theory of Postmodern Feminism has been applied to seek the answers that bring to notice the alluding characteristics of anti-essentialism and that of the protagonist and the relinquishing of pre-defined gender roles by her. Judith Butler's theory of Performativity has been applied because of Gilbert's subversion of the power structure of gender and challenging her pre-defined gender roles and thereafter establishing the point of Performativity by embarking on her journey towards self-discovery.

\section{REVIEW OF LITERATURE}

Prior researches conducted on Gilbert's memoir mainly surround critical aspects like Travel Narratives, Consumerism, Spiritual Quest, Food Symbolism, Post-Feminism and the like, leaving the study of the book in the light of Postmodern Feminism unexplored.

In a research article "Mysticism Meets Lifestyles: Elizabeth Gilbert" written by Dilge Kodak (2011), the scholar considers Elizabeth Gilbert as portrayed in the movie Eat Pray Love as a postmodern consumer and the paper "examines the postmodern consumer's relations with mystic experiences." (p. 39) The aspects of postmodernism, individualizations, mysticism, and the New Age Trend vis-à-vis the protagonist in the movie Eat Pray Love have been discussed. Discourse Analysis of the movie has been done keeping in mind the above aspects. The paper discusses the aspect that the modern consumer and the marketplace have been made to correspond to each other which in turn benefits both. The mystic lifestyles and culture of different places (Italy, India, and Indonesia, in this case) have been depicted as corresponding to the postmodern self that Gilbert now is.

Another scholarly article, "Food, Sex, Love, and Bodies in Eat Pray Love and Black Swan" by scholars Janani Subramanian and Jorie Lagerwey (2013) discusses the literal embodiment of the female protagonists, in Eat Pray Love and Black Swan, of the "... contradictory claims of Post-feminism in relationship to consumption, specifically the regulation of bodily appetites through either extreme discipline or a strictly delimited indulgence" (Subramanian \& Lagerwey, 2013 , p. 1). This paper focuses on the different eating patterns as showcased by two women; Elizabeth Gilbert in the movie Eat Pray Love appreciates and indulges 
herself into deliberate eating when she travels to her first destination, Italy and on the other hand, the protagonist in the movie Black Swan deliberately puts herself into a calorie deficit diet for attaining the body required to be the prima ballerina. The paper further moves on to discuss the impact of the popular culture of cinema and post feminism on the depiction of the relationship between female protagonists and food, sex, love, and their bodies, "ostensibly offering choice, but still requiring women to operate within strict, 'balance', boundaries of the acceptable when it comes to food, sex, love, and bodies" (Subramanian \& Lagerwey, 2013, p. 17).

The aspect of 'woman' has been discussed about in various ways; in a research article, "Food Symbolism, Sexuality, and Gender Identity in Fairy Tales and Modern Women's Bestsellers", Natalia Andrievskikh (2014) discussed the food imagery prevalent across fairy tales and contemporary literature, which alluded to women. The scholar compared the affinity of the novel with the ancient folklore's portrayal of the female protagonist's search for self-fulfillment and romantic love thus discussing the journey of Gilbert and the emancipation it provided her with.

The reading of Postmodernism and Post feminism has been conducted mostly on the film adaptation of Eat Pray Love exploring the theme of consumerism and the impact the movie has had on the travel industry of the three countries that it talks about, talking about the altered consumer behaviour and such leaving unexplored the study of the book in the light of Postmodern Feminism which this paper has set out to do.

\section{METHODS}

To establish the notions of Postmodern Feminism into Eat Pray Love, a critical analysis of the text was conducted by the researchers. The theory required studying and analyzing various other prevailing thoughts around it by prominent theorists. The study investigated various aspects of Postmodern Feminism as it is such a wide concept and selected the aspect of 'Non-Essentialism' that forms the major standpoint of the theory. Prominent points from the text were picked and fit into the realm of the theory.

\section{RESULTS AND DISCUSSIONS \\ Relating Essentialism to Postmodern Feminism and Eat Pray Love}

Often, we feel the obligation to perform in society in a specific way in our everyday lives. This 'specific' way is already predefined many times by the society while other times it is the result of our own continued behavioural patterns over a period. When we act, people expect us to act that way again. Also, there are certain premonitions about how a specific gender must behave, act, and for that matter, live his/her life. Hereon, the concept of essentialism comes into play. Essentialism is the view that things have 'essences', specific traits which define an entity/object what it fundamentally is, thus having the view 
that every entity/object must conform to its definition with all the specific characteristics to qualify as that particular entity.

Essentialism in everyday aspects also includes Gender Essentialism, which is the kind the researchers will here be talking about. Gender Essentialism sets specific characteristic traits to specific gender adhering to which they are fundamentally termed as masculine/feminine, meaning that there are certain rules ascribed under the concept of Gender Essentialism for being a 'man' or a 'woman'. Considering feminist theories and gender studies, it can be said that Gender Essentialism attributes a specific 'essence' to femininity. Feminist theorist Elizabeth Grosz (1995) states in her book, Space, Time and Perversion: Essays on the Politics of Bodies, that Essentialism

entails the belief that those characteristics defined as women's essence are always shared by all women. It implies a limit of the variations and possibilities of change- it is not possible for a subject to act in a manner contrary to her essence. Her essence underlies all the apparent variations differentiating women from each other. Essentialism thus refers to the existence of fixed characteristic, given attributes, and ahistorical functions that limit the possibilities of change and thus social reorganization. (pp. 47-48)

"I was trying so hard not to know this, but the truth kept insisting itself to me" (Gilbert, 2006, p. 10). What was that thing that the protagonist was "trying so hard" (Gilbert, 2006, p.10) not to know? Why did she not want to acknowledge the truth? Why was the truth insisting itself to her so much? The above sentence, extracted from the novel, said by the protagonist and followed by an internal monologue - "I don't want to be married anymore" (Gilbert, 2006, p.10) clearly gives the preliminary reader the hypothesis that the protagonist is, obviously married and is no longer happy in her marital relationship.

Elizabeth Gilbert was raised in a small countryside farm in Connecticut. She lived a common countryside life where the only time her parents would not ask her to do regular chores was when she and sister would be reading. Gilbert had been and lived the essentialist life since her childhood; her mother got married at twenty-four and had two kids, her sister got married at twenty-four and had two kids and Gilbert got married at twenty-four and suffered anxiety attacks when it was 'time' for her to have kids. In the memoir, Gilbert is seen daunting overturning thirty as it was ostensibly the right time to have kids and settle down. She says, “...that deadline of THIRTY had loomed over me like a death sentence, and I discovered that I did not want to be pregnant" (Gilbert, 2006, p. 13). Though Gilbert along with her husband had anticipated that she would want to "settle down and have children" (2006, p. 13), one of the major reasons why she thought she would want this life was because she had seen her mother and sister do the same, though following their lifestyle, as she eventually discovered, was not in unison with her desires. 
The meaning of the phrase 'settling down' has a rather Post-Structural approach to it, implying that its meaning is different in the context of men and women respectively. For men it has an economical connotative, getting a good job and getting married is when a man gets settled. On the other hand, it's meaning in the context of women means getting married and specifically having kids. Irrespective of a woman's flourishing career and financial independence, she is asked to 'settle down' i.e. to get married and eventually have kids. Gilbert had a fairly good job which had kept her and her husband afloat, she was the permanent earner of the family, her husband is seen switching jobs, exploring, and not taking any job dedicatedly. Even after being financially independent, being the consistent earner of the family, she was still expected to 'settle down' i.e. have kids.

The above argument leads to the understanding that gender and text (in this case a phrase) showcase similar characteristics. Post-structuralists argue that a text doesn't have a fixed meaning and for it to possess meaning it needs to be repeated continuously, also its meaning is context-specific. Likewise, gender also has no fixed meaning since its meaning is given to it by social construct hence making it vulnerable to change. As Pramod K. Nayar (2009) states in his book, Contemporary Literary and Cultural Theory,

Postmodern theories of gender argue that gender is not a fixed or stable category across the world. Gender, like a text, is a performance, the playing out of roles, that has to be repeated ('cited') and validated within specific social and cultural contexts, but which is also opened to contest and negotiations. ( $\mathrm{p}$. 130).

The researcher, during a personal interaction with the author, put up this question of the kind of pressure the author felt from the society and she answered,

The 'settling down' is not even pressure, it is beyond that. It's intrinsic, in drinkable; it's not that there was ever one source that I would say officially put this pressure on me. The entire culture, the entire structure of the culture; it's the assumption that this is what you do, and it's very rarely cut struck...(E. Gilbert, personal communication, January 23, 2020).

During this conversation, Gilbert does not fail to mention how she has known only one right way of doing things by witnessing her mother and sister doing it like it is supposed to be.

Essentialism does not just limit itself to things and gender(s), rather every single aspect about the civilization has been essentialised. Sigmund Freud's notion of Civilization in his book, Civilization and its Discontents (1930) and Butler's idea of Anti-Essentialism in her feminist texts like Gender Trouble (1990) and Undoing Gender (2004) reflect coherence in their ideas and thoughts. Freud (1994) tells us in his book that, Civilization is based on the renunciation of instinct/desire, and this is what is happening here with the protagonist, 
Gilbert, when she can be seen denunciating her instincts and her desires of not wanting to be in a marital relation any longer. So, can this be said that Civilization has been essentialized?

In the process of becoming more and more civilized and sophisticated, we have been made to conform to a specific way of living our lives, a specific time period which must be kept in mind when we are taking significant steps in life. This specificity takes the form of Essentialism and this is what Postmodern Feminism doesn't conform to.

Postmodern Feminism rejects any kind of restraining force that causes hindrance or pulls back a woman from taking necessary (in this case emergency) actions to free herself from this disguised oppression in the form of essentialised Civilization. The protagonist is a modern woman living in a first world country, she is working, in fact, the breadwinner of the family, despite possessing all these features which make their way to the list of 'prerequisites for being an independent, successful woman', Gilbert finds it terribly difficult for herself to simply acknowledge this fact that this wasn't the kind of life she wanted and she wanted to break free from it. It is often difficult for white-middle class women to acknowledge their oppression because they are at the top of the Western feminist thought, "Western feminist thought has taken the experiences of white middle-class women to be representative of the experiences of all women" (Spelman, 1988, p. 6). This makes her skeptical before realizing her desires. She is seen doubting her instinct because breaking away from a marriage isn't the true essence sub-consciously prevailing in the society following Essentialism. Looking at such things happening to an apparently independent woman- the slow, unconscious, and unintentional harmliving in a first-world country in the $21^{\text {st }}$ century is quite saddening and alarming. It transports us way back to the revolution of the Second Wave Feminism when women recognised that the only problem behind inequality was not just discrimination but also oppression in the form of unequal job opportunities, limited options in education, and various other everyday issues they had to face when going out in the men's world. The movement of Feminism has come a long way, winning basic rights and equality for women, from the First Wave up till contemporary feminist thoughts like Post Feminism and Postmodern Feminism, but looking at the protagonist here, this can be very well said that the movement requires an addition in the existing domain which requires keeping in consideration the needs of the middle-class whitewomen. Since these women are at the top of the hierarchy of the category of 'woman' so they are assumed to be free of problems of any sort. Elizabeth V. Spelman (1988) in her book Inessential Women: Problems of Exclusion in Feminist Thought says,

...some of the differences among women carry with them differences in privilege and power. Such differences may become problematic for the privileged women as the occasion for fear, shame, and guilt. In such circumstances, the 
"problem of difference" is really the problem of privilege. (p. 90).

The irony about being a first-world oppressed woman can be seen in the form of Gilbert's embodiment of it, where seemingly she is happy because she has got everything that a third world woman deeply desires for, but the fact remains that she is still oppressed, and she is not happy. This phenomenon is identified by the researchers as "Disguised Feminism". Spelman talks about how Western feminist thought has taken into consideration the lives of middle-class whitewomen as the pedestal for estimating gender oppression on "other women", without even realising they generalise the entire category of 'women' by doing it. Also, in this process it is often forgotten that the privileges of the middle-class white women also damage her in certain ways, “...such privilege damages (albeit in different ways) both the women who have it and those who do not..."(Spelman, 1988, p. ix).

The problem identified by Spelman regarding the generalisation of the category of women and considering middle-class whitewomen to be representative of the entire category of women in turns essentialises the roles, lifestyles, and the thought process of middle-class whitewomen thereby taking away from them the true essence of equality and freedom. Gilbert finds it extremely difficult to acknowledge her desires in the fear of breaking the social code and hence, goes through a whirlpool of emotions of shame, guilt, fear, and anxiety.

\section{Exploring Butler and Her Theories Concerning Performativity}

The inability of women to accept their true, actual selves is mainly because of the continuous repetition of specific gender roles ascribed upon them by the society. When Simone de Beauvoir (1984) claims, "one is not born, but rather becomes a woman" (p. 267), she is emphasising and reinterpreting this doctrine of constituting acts from the phenomenological tradition. This behavioural inconsistency of the gender is mainly elaborated by Butler, for the first time, in her seminal text, Gender Trouble (1990), and in her essay, "Performative Acts and Gender Constitution: An Essay in Phenomenology and Feminist Theory" (1988),

In this sense, gender is no way a stable identity or locus of agency from which various acts proceed; rather, it is an identity tenuously constituted in timean identity instituted through a stylised repetition of acts. Further, gender is instituted through the stylization of the body and, hence, must be understood as the mundane way in which bodily gestures, movements, and enactments of various kinds constitute the illusion of an abiding gendered self. (Butler, 1988, p. 1).

Gilbert's behaviour towards understanding her own passion and desires can very well be understood using Butler's theory of Performativity. According to Butler (1999), there is no easy way to separate the life of gender from the life of 
desire (paraphrasing). Our identity is very much affected by our passions and desires. In Merleau-Ponty's (2002) reflection in The Phenomenology of Perception on the body in its sexual being he takes up the issue with such sexist elaborations of bodily experience and claims that the body is a historical idea rather than a natural species. This claim is furthermore carried forward by Simone de Beauvoir (1984) in The Second Sex when she claims that 'woman,' and by extension, any gender, is a historical situation rather than a natural fact. Associating a biological female with feminine qualities provides the essentialist aspect to the framework of a female. Butler's theory, her ideas, her perception, all comes to play in the book Eat Pray Love portraying a woman who is trying to run away from the naturalized conception of gender. When Gilbert chooses to follow her desire, she constitutes her gender differently, thus establishing Butler's view that gender is constructed through performance and most importantly, if gender can be constructed by the society in a naturalized way then it can be constructed differently.

\section{Charting the Course of Postmodern Feminism}

In social sciences, 'agency' is the capacity of individuals to act independently and to make their own free choices. By contrast, structures are those factors of influence (such as social class, religion, gender, ability, customs) that determine or limit an agent or its decisions. And as such, Agency is a vex subject for Butler because she does not want to rely on a concept of the self that sees the self as an author of everything that happens in the world. She wants a self, or an agent, that is not just a victim or an effect of norms. The self is never outside of cultural influences but is not/should not simply be determined by those influences. By reading Gilbert, it has been observed that she had been trying to strike a balance between her Agency and the Structures surrounding her. She states this over and over in the preliminary pages of the book, "I was supposed to want to have a baby" (Gilbert, 2006, p. 10); "My husband and I had built our entire life around the common expectation that, after passing the doddering age of thirty, I would want to settle down and have children" (Gilbert, 2006, p. 10); "I'd been attempting to convince myself that this was normal" (Gilbert, 2006, p.11). It takes a whole lot of anticipation and speculation by Gilbert to fully take control of her agency and let go of the structures binding herself and her agency. The structure can be considered not too brutal in the case of a first world country woman, but the struggle as can be understood by reading Gilbert is clearly due to continuing norms of Gender Essentialism which has been continuing and still prevailing in the society so much so that it has become a default way of living in the society. Gilbert questions her agency and instinct because she has seen her mother and sister do the same thing that she is now expected to be doing and, she herself couldn't know why she desired something else when she had put efforts into the making of the clichéd way of life (approved by the society). 
De Beauvoir (1984) stated in The Second Sex that the woman was designated as the 'Other'. The 'Other' is termed so because women have continually been subservient to the male. Their actions must be dependent on their male counterparts, they are like the other hand of the compass which draws the circle while the hand at the center is stable and directs the other hand, just like the metaphysical conceit made by John Donne (1633) in Valediction: Forbidding Mourning. No option has been given to explore the dimensions of her own feelings, thoughts, wishes because the way a woman is "supposed" to feel is incorporated into her through the culture she grows up in, by her family values and by assessing other women in her family who are already bound into the essentialist lifestyle. Meaning that the first space where essentialist traits are inherited is the home. "The significance of place and its relationship to gendered identities...rely(ies) on a fundamental and essentialist binary distinction that maps onto gender divisions" (Eagleton, 2008, p. 12). The roles of men and women have already been predefined according to their gender roles; "men were the idealized rational, full participants as workers in the public arena of the economy and politics, women were dependents, to be protected and kept close" (Eagleton, 2008, p. 12). The first power structure is witnessed, and accepted as true, by both genders at home, "For most women, the home is a site of social relations that are structured by power and inequality" (Eagleton, 2008, p. 15). Learning from the lives of her mother and sister when
Gilbert builds her house and is expected to promote herself to the role of a mother, she experiences withdrawal from her lifestyle she says, "We'd only bought this house a year ago. Hadn't I wanted this nice house? Hadn't I loved it? So why was I haunting its halls every night now... Wasn't I proud of all we'd accumulated- the prestigious home in the Hudson Valley, the apartment in Manhattan...?" (Gilbert, 2006, p. 12). But without Gilbert's realization her house had become another structure of power in her life which made her realize every now and then that she needed to serve the purpose of having a big house - have kids.

The home is also, as Foucault (1976/1978) argued so persuasively, "the location of self-surveillance that ensures that even in the most private of acts the capillary structures of power in a modern state make certain that most behavior conforms to societal norms" (p. 15).

The researchers would like to talk about the concept of 'The Eternal Feminine', first introduced by Goethe (1994) at the end of Faust, Part 2 with reference to its relativity with the ongoing study. The Eternal Feminine propagates Gender Essentialism by having certain specific beliefs regarding particular 'essences' being possessed by male and female which cannot be altered by time or environment. De Beauvoir considered this as a myth and was adamant to shatter its ideology. She claimed that this myth was formed over time and produced by human civilization. The Eternal Feminine attributes qualities such as inferiority, gentleness, and emotionality to women and 
assumes them to be innate and fixed. For de Beauvoir, on the other hand, no essential characteristic should determine how one becomes a woman (Chaudhuri, 2006). De Beauvoir (1984) discussed at length about this aspect in her book The Second Sex. This is further elaborated by Betty Friedan (1963) in her book The Feminine Mystique which became the reason for the upsurge of the second wave feminism. Freidan wrote about, "the problem that has no name" (p. 3), which basically discussed the increasing melancholy in American housewives despite having every material comfort and possessing everything that a woman is supposed to achieve in her life (getting married, having children and being an all-rounder housewife). The detrimental effect induced by this image was that it narrowed women into the domestic sphere and led many women to lose their own identities. Friedan, in the conclusion of the first chapter says that, "We can no longer ignore that voice within that says: 'I want something more than my husband and my children and my home." (Friedan, 1963, p. 32).

Studying and analyzing the feminist revolution since de Beauvoir, the struggle and evolution of women can be noted; the researchers believe that the process of a woman's struggle and achieving liberation at the end is still working out like the same way in the $21^{\text {st }}$ century as was at the start of these revolutions. A woman is still considered as 'The Eternal Feminine' who must do all the feminine chores and seek fulfilment and happiness in the roles assigned to her by the society, as the protagonist here Elizabeth Gilbert was doing; next she has been identified as 'The Feminine Mystique' who is unhappy and dissatisfied with her life which is supposed to be perfect and blissful as it conforms to society's regulations, the embodiment of which can be seen in and as Gilbert, who is questioning herself and why her perfect life is not able to give her the happiness which it was supposed to provide her with.

To overcome all these feminist issues, which Friedan rightly calls 'the problem that has no name', Postmodern Feminism comes into play. Postmodern Feminism propagates having no boundaries, no 'Feminist' name tag because ultimately that name tag also limits women to being beyond or outside the horizons of Feminism, dropping the burdens of Gender Essentialism, Gender Stereotypes, and Gender Dichotomies. The Postmodern Feminist lets go of the 'performances' that bind her into certain gender norms. Because Gilbert had seen and learnt from her mother and sister a way of living, where females are meant to grow up, get married, fulfil all the responsibilities that come with getting married, bear children when 'she comes of age', and always cater to the needs of her husband and her family, even she succumbed to essential gender norms and tried her best to live her life in an 'essentialised' way. Gilbert has a conversation with her mother right before she was leaving for Italy where she thinks of her mother as this very strong, self-sufficient woman, 
What I grew up watching in my household was a mother who would receive her husband's love and affection whenever he thought to offer it but would then step aside and take care of herself whenever he drifted off into his own peculiar universe of low-grade oblivious neglect. (Gilbert, 2006, p. 86).

But living in a postmodern world, Gilbert soon started realising what her true desires were and that she could never find solace in the materialistic things around her which were supposed to provide her happiness. After a lot of speculation, questioning herself, and self-loathing, she finally takes the step to end her marriage and seek out herself, spend some time just with herself without the emotional presence of any man in her life.

'Representation' plays a dual role. Butler (1999), in Gender Trouble, talks about "Subjects of Sex, Gender, and Desire" in chapter one. Here, she talks about the representation of women. In the political arena, it serves as the operative term within a political process that seeks to extend visibility and legitimacy to women as political subjects. "On the other hand, Representation is the normative function of a language which is said either to reveal or distort what is assumed to be true about the category of women" (Butler, 1999, p. 1). If the theory of 'the center shift' by Derrida is applied here as woman is always striving to be the subject as her role is always been compared with her relation to a man, her role has always been that of an object because men has already taken up the role of the subject. Postmodernism sure does incorporate and features 'Otherness', but women still feel as the object and constantly try to make the center shift and be the subject. Butler, in this context has the view that "the qualifications for being a subject must first be met before representation can be extended" (1999, pp. 1-2). Woman becomes an impossible category in this kind of a discursive situation because a woman can never be in complete conformity to that certain parameter because that parameter is very phallogocentric in approach. So, women will always be short of the permitted qualities. Butler (1999) further said, women were not substance, rather they were the 'difference'; because they differed from the normative angle. Women are always excluded from the domain. But women cannot be simply negated from the domain, they cannot be termed as the 'other'. Woman is the 'difference' in the identity, they are not the 'other'. 'Other' is an identity while 'difference' is a process which produces the otherness. Thus, Butler totally withdraws woman from this race of being the subject or the other stating that woman is the 'difference' because the parameters are set as such that women will never be able to take the pivotal position as the foundation of such operations have been laid by men making it entirely phallogocentric.

The researchers would like to quote an example from the Netflix series, Dead To $M e$ which is an American black comedy web series created by Liz Feldman (2019), where the female protagonist laments how she gave up her desires so that she could earn a 
decent living for her children and her nonworking husband. Exactly like Gilbert, she finds her petty desires to be too silly to be put into actualization now. The protagonist (Jennifer aka Jen) is in conversation with her friend (Judy):

Jen: Did I tell you Laguna is his hometown, right? It's where he wanted to live, where he felt safe. It's, like, I just had to figure it out how am I gonna make money, feed four mouths.

Judy: But you did, you made a beautiful life.

Jen: What life? This isn't my life. This is his life. I worked to support him and his dreams. I had my own dreams.

Judy: Your dreams, what were they?

Jen: They're stupid now.

Judy: No!

Jen: No! It's embarrassing.

Judy: C'mon.

Jen: I wanted to be a dancer. I was pretty good too. But it just... seemed like his career was taking off and I'm the one with the uterus and I've gotta be the grown-up here and for what? (S1, E4).

The continued usage of the word 'petty' for addressing the desires of both Gilbert and Jen (protagonist in Dead To Me, 2019) has been done to bring into notice the actual minuteness of the desires of both the female characters. One of them simply wanted to buy a "pencil box" (Gilbert, 2006, p. 24) for herself while the other one wanted to be a dancer. Perhaps, Gilbert did not desire a pencil box per se, she just wanted to speak out her desires out loud. She explains how initially she did not even dare to answer the question, "What do you want to do, Liz?" (Gilbert, 2006, p. 24) And when she began answering this question, she could not dare realizing bigger desires rather she started with the little ones, she says, "And when I finally started to answer, I did so cautiously. I would only allow myself little baby-step wants" (Gilbert, 2006, p. 24).

\section{CONCLUSION}

After analysing the above arguments of Gender Essentialism and the theory surrounding Gender difference (female as the 'Other', male as the 'Subject') it can be said that Gender Difference propagates Gender Essentialism and vice versa. The 'Difference' is 'Essentialised' to such an extent now that it doesn't seem to be coming the wrong way. The legitimisation of the difference has taken place so much so that it is now the accepted and apparently the right way to do things. The realisation of the difference taking place in the lives of women is dormant now; they have accepted the state of things and have started to believe in them. Gilbert's uncertainness regarding her marriage has already been discussed in the above pages. She continually questions her premonitions about her failing marriage; she considers leaving her marriage a sin and continually loathes herself for considering doing it. According to her life experiences till now, seeing her mother and sister and various other women being good wives and bearing children at the right age and taking 
good care of the entire household is actually the right way for a woman to live her life and what she is doing totally contradicts that way. Various societal norms and the widely accepted 'essentialised' way of life led her to believe that what she's doing maybe right in her perspective but is certainly not the desirable way. This directly alludes to Freud's thought in his Civilization and its Discontents (1930), where he says that civilization creates rules against what we want, these rules exist out of a civilizing function that in order to have peace and some sense of security in the society we need to renounce desire and instinct. The society governed by civilizing principles have created rules which renounce the basic instinct and desire of Gilbert disallowing her to follow her heart and instead accept the normal 'essentialised' and 'civilized' way of existing as a woman.

Talking in terms of gender and sexuality, when one renounces one's basic desire and instinct, one is in turn giving in to the expectation of a civilized society which leads to certain performativity performed by specific genders. Hence, it can be said that "...gender identity is a performative accomplishment compelled by social sanction and taboo." (Butler, 1988, p. 520) propagated by the civilization of the society. Butler's theory of Performativity claims that the roles of sex and gender are not prescribed at birth rather they are formed over time by certain performances of the sex. In Butler's essay, "Performative Acts and Gender Constitution: An Essay in Phenomenology and Feminist Theory" (1988, p. 519), she says, "In this sense, gender is in no way a stable identity or locus of agency" (p. 519). When Gilbert performs out of her gender roles by deciding on not having kids, getting a divorce and travelling to the places she wanted to, she establishes Butler's point that gender is itself the effect and not the origin or cause hence establishing its claim of no stable identity.

Butler distinguishes 'Performance' from 'Performativity' saying that 'Performativity' means an act that not only communicates but also creates an identity. Performative acts of gender do a similar kind of work, not only communicating to others some aspect of identity, but constructing that very identity, only they do that work through repetition. This can be noticed in Gilbert's behaviour as well, she rejects her gender roles by not conforming to society's norms and moving away from already accepted female gender roles of 'settling down' which means marrying, having kids, and living in a respectable household by a certain age.

The aspect of Postmodern Feminism has been explored within the chosen text with the establishment of certain common and strong aspects prevalent in both. The memoir by Elizabeth Gilbert proves to be a suitable platform to propagate the concepts of Postmodern Feminism which exists even in the lives of first world independent women. Butler's Performativity, the aspect of NonEssentialism, basically the standpoints of the theory are given justice to in Gilbert's text. This research paper has aimed to bring into light the issues still faced by women in the world by taking the example of 
Elizabeth Gilbert and her journey towards self-discovery.

\section{ACKNOWLEDGEMENT}

We would like to express our gratitude towards our family, our institution, our mentor and the almighty for gracing us with the opportunity and considering us capable enough to conduct research.

\section{REFERENCES}

Andrievskikh, N. (2014). Food symbolism, sexuality, and gender identity in fairy tales and modern women's bestsellers. Studies in Popular Culture, 37(1), 137-153. Retrieved May 7, 2020, from https://www.jstor.org/stable/10.2307/ 24332704 ? seq $=1$.

Butler, J. (1988). Performative acts and gender constitution: An essay in phenomenology and feminist theory. Theatre Journal, 40(4), 519-520. doi: $10.2307 / 3207893$

Butler, J. (1999). Gender trouble: Feminism and the subversion of identity. New York, USA and London, England: Routledge.

Chaudhuri, S. (2006). The eternal feminine. In Feminist film theorists: Laura Mulvey, Kaja Silverman, Teresa de Lauretis, Barbara Creed (p. 16). London, England: Routledge.

de Beauvoir, S. (1984). The second sex. New York, USA: Random House.

Donne, J. (1633). A valediction: Forbidding mourning by John Donne. Poetry Foundation. Retrieved September 30, 2019, https:// www.poetryfoundation.org/poems/44131/avalediction-forbidding-mourning

Eagleton, M. (2008). A concise companion to feminist theory. Cornwall, England: John Wiley \& Sons.

Feldman, L. (Director), Hardesty, J., Cardellini, L., Chomsky, P., \& Enright, B. (Producers). (2019).
Dead to me [Television series]. Retrieved November 18, 2019, from http://www.netflix. com

Foucault, M. (1978). The history of sexuality: An introduction (R. Hurley, Trans.) (1st ed.). New York, USA: Vintage. (Original work published 1976).

Freud, S. (1994). Civilization and its discontents. New York, USA: Courier Dover Publications.

Friedan, B. (1963). The feminine mystique. New York, USA: W. W. Norton \& Company.

Gilbert, E. (2006). Eat pray love: One woman's search for everything across Italy, India and Indonesia. London, England: Bloomsbury Publishing.

Goethe, J. W. (1994). Faust, part two. New York, USA: Oxford University Press, USA.

Grosz, E. A. (1995). Sexual difference and the problem of essentialism. In Space, time, and perversion: Essays on the politics of bodies (pp. 47-48). doi: $10.4324 / 9781315656564$

Kodak, D. (2011). Mysticism meets lifestyles: Elizabeth Gilbert. Journal Academic Marketing Mysticism Online, 1(3), 39-55. Retrieved December 15, 2019, from http://www. journalacademicmarketingmysticismonline.net

Merleau-Ponty, M. (2002). Phenomenology of perception. London, England: Psychology Press.

Nayar, P. K. (2009). Feminisms. In Contemporary literary and cultural theory: From structuralism to ecocriticism (pp.116-167). New Delhi, India: Pearson Education India.

Spelman, E. V. (1988). Inessential woman: Problems of exclusion in feminist thought. Boston, USA: Beacon Press (MA).

Subramanian, J., \& Lagerwey, J. (2013). Food, sex, love, and bodies in "Eat Pray Love" and "Black Swan”. Studies in Popular Culture, 36(1), 1-20. Retrieved May 7, 2020, from www.jstor.org/ stable/ 10.2307/23610149 